\title{
INFLUENCE OF LOCAL BRANDS ON DOMESTIC INVESTORS' DECISION TO SELECT INVESTMENT LOCATIONS: CASE STUDIES IN VIETNAM
}

\author{
Ai Huu Tran \\ Thu Nguyen Thi Mong \\ My Phan Thị Chieu \\ Van Hien University, Ho Chi Minh city, Vietnam
}

The objective of the research is to explore and determine the influence of some factors on the investor's decision to choose a location in Vietnam. The survey was conducted in Vietnam with the total of 350 copies distributed and 312 collected, of which 284 copies were satisfactory for analysis. The research results show that shaping positive attitudes and behaviors towards local brands concerns not only each investment business but also the investment environment of each locality overall.

Keywords: investment decision-making; investment location; local marketing; Vietnam

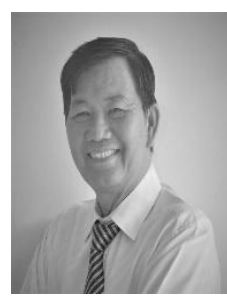

\section{Ai Tran Huu}

$\mathrm{PhD}$, Lecturer at the Faculty of Economics, Van Hien University, Ho Chi Minh City, Vietnam.

Research interests: agricultural product markets; organic food markets; ecological economics; environmental issues of economic development; corporate social responsibility.

E-mail: aith@vhu.edu.vn

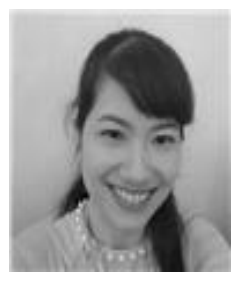

\section{Thu Nguyen Thi Mong}

MBA, Lecturer at the Faculty of Economics, Van Hien University, Ho Chí Minh City, Vietnam.

Research interests: SMEs functioning and government support; organic food markets; environmental economics.

E-mail: thuntm@vhu.edu.vn

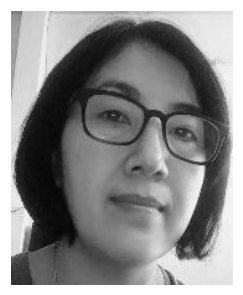

\section{My Phan Thi Chieu}

MBA, Lecturer at the Faculty of Economics, Van Hien University, Ho Chí Minh City, Vietnam.

Research interests: markets of agricultural products; SMEs functioning; organic food markets.

E-mail: thuntm@vhu.edu.vn 


\section{Introduction}

Today, localities are facing major environmental, financial, and economic challenges that require structural change and strategic thinking to compete and cope with these challenges. At the same time, localities must also compete with each other, namely, for attracting investment capital for further socioeconomic development. In local marketing, any investor is seen as a local customer. Thus, it is essential to understand investors' needs and behavior.

From the local marketing point of view, location is one of the 6Ps that plays an important role in the survival and growth of a business. At the same time, local investment and business environment are also considered to be local products. Target markets for these particular commodities include tourism, export markets, domestic and international investors. Among these customers, investor is the main target for a developing locality. Another highlight often mentioned by many researchers is local brand. In a fiercely competitive world attracting investments, other forms of capital, people, resources, etc. into localities is often built on an attractive image, clear positioning, and absolute confidence (Nguyen \& Haughton, 2002; Mmieh \& Owusu-Frimpong, 2004).

Each locality needs a number of important development sites to stimulate the inflow of domestic and foreign investments as well as to create a high level of satisfaction among investors, this especially concerns developing countries (Cleave et al., 2016).

Another theoretical point mentioned by many researchers is that local brands influence investors' decisions concerning the location of future investments (Jacobsen, 2009; Metaxas, 2010). At the same time, empirical studies testing how local brand equity affects investors' decisions is still quite modest in numbers and volume (Jacobsen, 2009).

In Vietnam today, research on local brands, especially the influence of local brands on investors' decisions on choosing investment locations is still very limited. The available to date studies can be divided into two main research directions: the first one concerns local brand names as the factor influencing investors' decisions (Nguyen Viet Bang et al., 2016). The second research direction explores the aspect of local brand attributes affecting investor satisfaction (Dao Trung Kien et al., 2014). These research results are not necessarily true for domestic investors however. In terms of spatial scale, the above studies were mainly carried out in the southern provinces of Vietnam (Tien Giang, Dong Nai, Nha Trang). Other studies mainly focus on assessing the current state of local marketing through the available marketing tools.

\section{Theoretical basis}

\section{Product / service brand}

A trademark is a name, design, logo, or any other feature that distinguishes one seller's products or services from those of another. A brand can identify a single product, a series of products, or all of the seller's items. Trademarks include names, signs, and symbols identifying goods and services and distinguishing them from competitors' goods and services (Aaker, 1991). Keller (2003) provided an alternative viewpoint on brand: it is a set of associations in the minds of customers that increase the perceived value of a product or a service. 


\section{INFLUENCE OF LOCAL BRANDS ON DOMESTIC}

\section{Local brands}

Local brands are built up just like those of products or services (Hankinson, 2001). Local brands are like corporate brands, thus, they can benefit from the value of a local image (Rainisto, 2003). A locality is a brand entity if its own characteristics distinguish it from other units of similar weight (Kavaratzis, 2005). Zenker \& Braun (2010) introduced the concept as follows: "A local brand is a collection of brand associations in the minds of consumers based on behavioral expressions, locality expressed through purpose, values and the common culture of the stakeholders and the master plan of that locality".

\section{Local brand property}

Brand equity covers different effects of brand knowledge on consumer responses as per brand's marketing program, while high brand knowledge increases brand choice (Keller, 2003). Davis \& Douglass (1995) argued that brand equity is willful and emotional selection carried out by consumers towards brands. Papadopoulos (2004) argued that local brand equity includes "real or perceived assets, attached to one locality and distinguishing it from others".

Kotler et al. (1993) wrote that localities, as well as products and services, need to be subtly marketed. Each locality needs to identify its special features and competitive advantage to seek customer support. To achieve this, local brands need both cognitive and emotional values. Accordingly, from the investor's perspective, local brands have three functions that need to be defined (Meffert, 2000).

\section{Local brand equity elements}

In today's world, there are many different perspectives on brand equity and the elements of brand equity. Aaker (1991) became one of the first scholars to build a model of brand equity and the elements of brand equity which includes five main components: brand awareness, perceived quality, brand associations, brand loyalty, and other proprietary assets. See other suggestions on what are the elements of brand equity in Tab. 1 below.

Table 1 - Local brand equity elements

(made by co-authors)

\begin{tabular}{|c|l|l|}
\hline Types of assets & \multicolumn{1}{|c|}{ Assets } & \multicolumn{1}{|c|}{ Source } \\
\cline { 2 - 3 } Material & Perceived quality & Jacobsen (2009) \\
\cline { 2 - 3 } & Brand impression & Kavaratzis (2007); Dinne (2008); Jacobsen (2009) \\
\cline { 2 - 3 } & Local brand image & $\begin{array}{l}\text { Dinne (2008); Jacobsen (2009); } \\
\text { Zenker \& Braun (2010); Jacobsen (2009) }\end{array}$ \\
\hline \multirow{3}{*}{ Intangible } & Brand awareness & $\begin{array}{l}\text { Zenker (2011); Jacobsen (2012); Bose et al. (2016); } \\
\text { Chekalina et al. (2016). }\end{array}$ \\
\cline { 2 - 3 } & Local brand personality & $\begin{array}{l}\text { Risitano (2005); Jacobsen (2009); Baxter and Kerr } \\
\text { (2010); Zenker (2011); Jacobsen (2012). }\end{array}$ \\
\cline { 2 - 3 } & Local brand trust & Jacobsen (2009); Jacobsen (2012). \\
\hline
\end{tabular}




\section{Research model and hypotheses}

\section{Research hypotheses}

On the basis of an overview of previous studies, especially Jacobsen's (2009, 2012), combined with the research context in Vietnam specifically, the author proposes the research hypotheses as follows:

\section{- Local brand personality}

The personality of a local brand has a significant impact on the decisions of local customers when they are deciding to reside, visit, or invest locally. This can happen when local customers perceive the personality of a local brand that reflects their personality (Sirgy, 1982). The Research by Jacobsen (2009) also concludes that local brand personality has a strong influence on investors' choice of location. Therefore, the author hypothesizes as follows:

H1: Local brand personality has a positive relationship with domestic investors' decisions to choose investment locations.

\section{- Local brand awareness}

Local brand awareness helps local customers familiarize themselves with local brands and helps them care about the locality at the time they are making a local choice. A popular local brand will be more trustworthy, thus providing an opportunity for customers to review and promote brand choice as a destination. The research by Jacobsen (2009) has confirmed that brand awareness has a strong impact on investors' decisions to choose investment locations through local brand benefits. Therefore, the author hypothesizes as follows:

H2: Local brand awareness has a positive relationship with domestic investors' decisions to choose investment locations.

\section{- Perceived quality}

When studying local brands from the perspective of destination, Jacobsen (2012) has found a positive relationship between the perceived quality of destination and the destination choice. In addition, he provided evidence to prove that perceived quality has an impact on investors' decisions to choose investment locations. Therefore, the author hypothesizes as follows:

H3: Perceived quality is positively related to domestic investors' decisions to choose investment locations.

\section{- Local brand impression}

A local brand impression refers to a local appearance that evokes positive emotions (Wang \& Hsu, 2010). According to qualitative research, a locality that makes a good impression in the eyes of investors is more likely to be chosen by them. Therefore, the author hypothesizes as follows:

H4: Impression that local brands have a positive relationship with the domestic investors' decisions to choose investment locations. 


\section{INFLUENCE OF LOCAL BRANDS ON DOMESTIC}

\section{- Local brand trust}

Local brand trust is emphasized in the research by Ramkissoon et al. (2011) and Jacobsen (2009). Local brand trust is the local customers' confidence in the local services provided by the local government's communication and commitment to investors concerning the services provided to customers. Therefore, the author hypothesizes as follows:

H5: Local brand trust has a positive relationship with domestic investors' decision to choose investment locations.

\section{- Local brand image}

Previous research on local brand image focused primarily on the destination brand image. Some researchers have shown that destination brand image is one of the main factors, having a significant impact on customer choice of a destination (Chi \& Qu, 2008; Wang \& Hsu, 2010). Therefore, the author hypothesizes as follows:

H6: Local brand image has a positive relationship with domestic investors' decisions to choose investment locations.

\section{Research Methods}

Table 2 - Description of the research sample $(\mathrm{N}=284)$ (made by co-authors)

\begin{tabular}{|l|l|c|c|}
\hline \multirow{2}{*}{ Content } & Quantity & $\begin{array}{c}\text { Ratio } \\
\text { (in \%) }\end{array}$ \\
\hline \multirow{2}{*}{ Gender } & Male & 179 & 63.03 \\
\cline { 2 - 4 } & Female & 105 & 36.97 \\
\hline Total & & 284 & 100.00 \\
\hline \multirow{2}{*}{ Type of investment } & Direct & 126 & 44.37 \\
\cline { 2 - 4 } & Indirect & 158 & 55.63 \\
\hline Total & & 284 & 100.00 \\
\hline \multirow{3}{*}{ Age group } & $>30<40$ & 148 & 52.11 \\
\cline { 2 - 4 } & $>40<50$ & 94 & 33.10 \\
\cline { 2 - 4 } Total & $>51$ & 42 & 14.79 \\
\hline \multirow{3}{*}{ Seniority in the industry } & & 284 & 100.00 \\
\cline { 2 - 4 } & $>5$ years & 56 & 19.72 \\
\cline { 2 - 4 } & $10-15$ years & 97 & 34.15 \\
\cline { 2 - 4 } & $>20$ years & 68 & 23.94 \\
\hline Total & & 284 & 100.00 \\
\hline
\end{tabular}

The survey was conducted in July-October 2020. The respondents were all representatives of investment businesses. These investors are randomly selected from the list of local planning and investment departments of three major cities - Hanoi, Da Nang, and HCM City. The respondents were approached in two ways: (1) direct contact with the representatives of the investment firms and investors; (2) sending out survey questionnaires through the email lists that the authors have collected in advance. 
Our questionnaire had 34 variables in total, thus resulting in a minimum sample of 170 people. The survey was conducted according to the simple random sampling method with the total number of questionnaires being $\mathrm{n}=350$. The response rate of the surveyed subjects was $89.2 \%$, or 312 votes obtained. The number of votes used in the analysis accounted for $90.55 \%$ of 284 votes ( 28 votes were rejected due to incomplete answers and/or when the subjects were choosing the same option in all the questions).

In our study, the observed variables were assessed using the Likert scale with five levels (where $1=$ very dissatisfied, level $2=$ dissatisfied, level $3=$ moderately satisfied, level $4=$ satisfied, and level 5 = very satisfied).

\section{Research results}

\section{Cronbach Alpha reliability coefficients of scales}

Tab. 3 shows that Cronbach's Alpha coefficients of all the scales are greater than 0.7, and the total variable correlation coefficients are greater than 0.4. Therefore, all the scales can be used in EFA and regression analysis.

Table 3 - Test results for Cronbach's Alpha's scales

(made by co-authors)

\begin{tabular}{|c|l|c|c|c|}
\hline $\mathrm{N}_{0}$ & \multicolumn{1}{|c|}{ Components } & Observations & Confidence & $\begin{array}{c}\text { Corrected Item-Total } \\
\text { Correlation }\end{array}$ \\
\hline 1 & Local brand personality (LBP) & 5 & 0.796 & 0.444 \\
\hline 2 & Local brand awareness (LBA) & 5 & 0.930 & 0.725 \\
\hline 3 & Perceived quality (PQ) & 5 & 0.831 & 0.532 \\
\hline 4 & Local brand impression (LBIN) & 5 & 0.875 & 0.589 \\
\hline 5 & Local brand trust (LBT) & 5 & 0.893 & 0.631 \\
\hline 6 & Local brand image (LBIE) & 5 & 0.912 & 0.608 \\
\hline 7 & Decision on investment location & 3 & 0.866 & 0.613 \\
\hline
\end{tabular}

\section{Exploratory factor analysis $(\mathrm{EFA})$}

The results of the exploratory factor analysis with promax rotation show that 33 observed variables in the 7 components of the scale for the decision on choosing the investment location kept all the 7 factors but only 30 observed variables. The excluded control variables included: LBA4, PQ4, and LBIE5. The KMO coefficient $=0.740$, thus, the EFA result is consistent with the Chi-quare data and statistics of the Bartlett test reaching 8117.465 with the significance level of 0.000 .

Therefore, the observed variables are correlated with each other on the overall scale. The variance extracted by 74.651 shows that the 6 extracted factors are explained from the $74.651 \%$ variation of the data, at the eigenvalue coefficient of 1.008 . Therefore, the scales drawn are acceptable. 
Table 4 - Summary of the scale test results (made by co-authors)

\begin{tabular}{|c|c|c|c|c|c|}
\hline $\mathrm{N}_{0}$ & Components & Observations & Confidence & $\begin{array}{c}\text { Deduction } \\
(\%)\end{array}$ & Evaluate \\
\hline 1 & Local brand personality (LBP) & 5 & 0.796 & 32.927 & \multirow{7}{*}{ Qualified } \\
\hline 2 & Local brand awareness (LBA) & 4 & 0.930 & 43.897 & \\
\hline 3 & Perceived quality (PQ) & 4 & 0.831 & 53.074 & \\
\hline 4 & Local brand impression (LBIN) & 5 & 0.875 & 61.480 & \\
\hline 5 & Local brand trust (LBT) & 5 & 0.893 & 66.906 & \\
\hline 6 & Local brand image (LBIE) & 4 & 0.912 & 71.290 & \\
\hline 7 & Decision on investment location & 3 & 0.765 & 74.651 & \\
\hline
\end{tabular}

Factor analysis for the independent variables (CFA)

\section{Confirmatory factor analysis (CFA)}

The correlation coefficient between the components with accompanying standard deviation (see Tab. 5) shows that these coefficients are less than 1 (with statistical significance). Therefore, such components as local brand personality (LBP), local brand awareness (LBA), perceived quality (PQ), local brand impression (LBIN), local brand trust (LBT), and local brand image (LBIE) have distinguishing values.

Table 5 - Results of testing the components of the scale (made by co-authors)

\begin{tabular}{|ccc|cccc|}
\hline & & & Estimate & S.E. & C.R. & P \\
\hline LBIN & $<->$ & LBIE & .080 & .027 & 2.949 & .003 \\
LBIN & $<->$ & LBT & .122 & .027 & 4.512 & $* * *$ \\
PQ & $<->$ & PBP & .046 & .015 & 3.123 & .002 \\
PQ & $<-->$ & LBT & .102 & .025 & 4.050 & $* * *$ \\
PBP & $<-->$ & LBIE & .044 & .016 & 2.681 & .007 \\
PBP & $<-->$ & LBT & .123 & .023 & 5.431 & $* * *$ \\
LBIE & $<->$ & LBT & .150 & .029 & 5.107 & $* * *$ \\
LBIN & $<->$ & PBP & .098 & .020 & 4.822 & $* * *$ \\
LBIN & $<->$ & PQ & .146 & .027 & 5.361 & $* * *$ \\
\hline
\end{tabular}

Regarding the general conformity, factor analysis confirmed that this model has a statistic value of chi-squared of 287.891 with 134 degrees of freedom $(p=0.000)$, relative squared chi according to the degree of freedom CMIN / $\mathrm{df}$ is $2.148(<3)$.

Other indicators are: GLI $=0.903(>0.9), \mathrm{TLI}=0.931(>0.9), \mathrm{CFI}=0.946(>0.9)$, and RMSEA $=0.065(<0.08)$. This allows us to draw judgment on the unidirectionality of the observed variables. Regarding the convergence value, the normalized weights of the scales 
are $>0.5$ and have statistical significance of $p<0.5$. Therefore, the scales achieve convergent values.

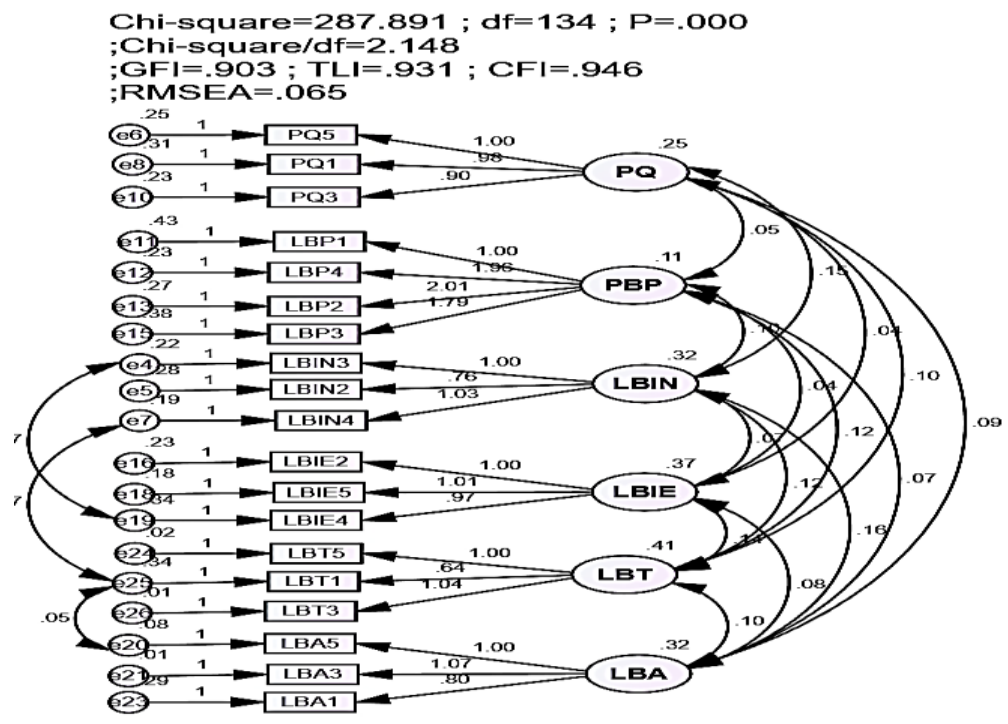

Figure 1 - CFA analysis results (normalized) (made by co-authors)

\section{Structural Equation Model Results}

The table below shows the results for the degree of conformity checking for the two structures, the characteristics of the studied SMEs and the accessibility of these SMEs and the result structure model for the two datasets. Various indices, namely the Absolute Fit Measurements and the Increased Fit Measurements are used to evaluate the model's fit. As a commonly used statistics for the model suitability index, Chi-square (X2) is used in this study to test the existence of any relationship between the variables in the model (Hair et al., 2006). From the AMOS results reflected in Table 7, it is clear that the model is consistent with the data and therefore the proposed model is suitable for explaining relationships between the variables.

Table 6 - AMOS results

(made by co-authors)

\section{Goodness of fit Measures}

$$
\mathrm{X} 2 / \mathrm{df}
$$

\begin{tabular}{ccccccccccc} 
Model & $\mathrm{X} 2$ & $\mathrm{Df}$ & $\mathrm{p}$ & $(\mathrm{CMIN} / \mathrm{DF})$ & $\mathrm{RMSEA}$ & $\mathrm{NFI}$ & $\mathrm{RFI}$ & $\mathrm{IFI}$ & $\mathrm{TLI}$ & $\mathrm{CFI}$ \\
\hline Sample & 261.442 & 120 & 0.000 & 2.179 & .066 & .908 & .912 & .948 & .933 & .947 \\
Criteria & $\mathrm{P}>.05$ & $\geq 0$ & - & 2 to 3 & $<.080$ & $>.90$ & $>.90$ & $>.90$ & $>.90$ & $>.90$ \\
\multicolumn{3}{c}{ (non-significant) } & & & & & & & &
\end{tabular}

Notes: $\mathrm{X}^{2}=$ Chi-square test, $\mathrm{df}=$ degrees of freedom, RMSEA $=$ root mean square error of approximation, NFI $=$ normed fit index, RFI $=$ relative fit index, $\mathrm{IFI}=$ incremental fit index, TLI $=$ Tucker-Lewis index, $\mathrm{CFI}=$ comparative fit index. 


\section{INFLUENCE OF LOCAL BRANDS ON DOMESTIC}

\section{Inspection of the relationship between the key variables}

The decision to choose an investment site is made up of five components. The obtained SEM results shown in Fig. 2 have the chi-squared statistical value of 261.442 with 120 degrees of freedom $(\mathrm{p}=0.000)$. The relative squared Chi square CMIN/df is $2.179(<3)$ which is acceptable for the sample of 284 observations, GFI $=0.904(>0.9)$, TLI $=0.933$ $(>0.9)$, CFI $=0.947(>0.9)$. RMSEA $=0.066<0.08$, thus proving that the scale model of factors of SMTH is consistent with the study data. Weights (normalized) are $>0.5$, and the normalized weights are statistically significant, so all the concepts under study achieve convergent values. Therefore, this model achieves compatibility with the collected data (Tab. 7) have P-values $<0.05$, and the estimated values are normalized so that they have a direct effect.

Table 7 - Regression Weights of the Model (made by co-authors)

\begin{tabular}{|lll|cccc|}
\hline & & & Estimate & S.E. & C.R. & P \\
\hline DLFI & $<---$ & PQ & .052 & .072 & .732 & .004 \\
DLFI & $<---$ & LBIN & .310 & .075 & 4.142 & $* * *$ \\
DLFI & $<---$ & PBP & .120 & .122 & .979 & .028 \\
DLFI & $<---$ & LBIE & .082 & .049 & 1.689 & .021 \\
DLFI & $<---$ & LBT & .029 & .053 & .555 & .019 \\
\hline
\end{tabular}

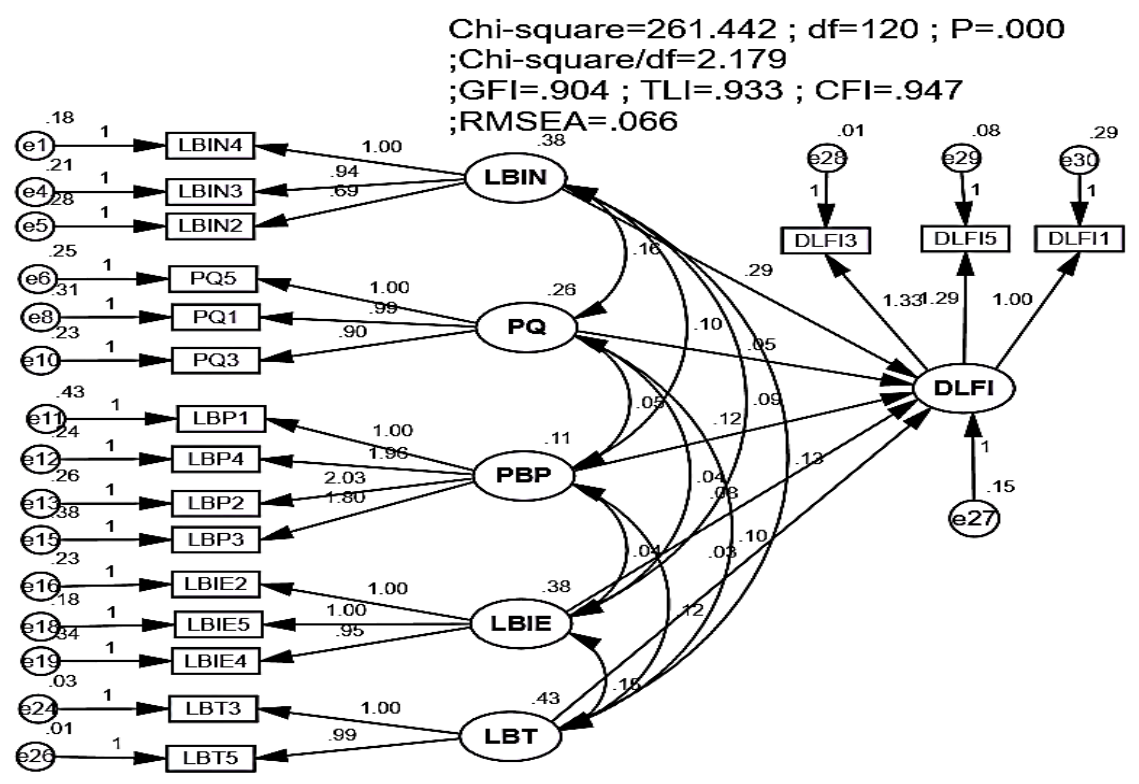

Figure 2 - SEM analysis results

(made by co-authors) 
Table 8 - Results estimated by bootstrap with $\mathrm{N}=1000$

(made by co-authors)

\begin{tabular}{|c|c|c|c|c|c|c|c|c|}
\hline \multicolumn{3}{|c|}{ Parameters } & SE & SE-SE & Mean & Bias & SE-Bias & CR \\
\hline DLFI & $<--$ & PQ & 0.088 & 0.002 & 0.052 & 0.000 & 0.003 & 0.000 \\
\hline DLFI & $<---$ & LBIN & 0.096 & 0.002 & 0.310 & 0.001 & 0.003 & 0.330 \\
\hline DLFI & $<---$ & PBP & 0.176 & 0.004 & 0.133 & -0.014 & 0.006 & -2.330 \\
\hline DLFI & $<---$ & LBIE & 0.068 & 0.002 & 0.082 & -0.001 & 0.002 & -0.500 \\
\hline DLFI & $<---$ & LBT & 0.074 & 0.002 & 0.033 & -0.004 & 0.002 & -2.000 \\
\hline
\end{tabular}

Testing the reliability of estimates by means of bootstrap

The bootstrap method has been used here to test the model estimates with the pattern repeat $\mathrm{N}=1000$. The estimation results from 1000 samples are averaged together with the deviations presented in Tab. 8. CR has a very small absolute value, lower than 2 , thus, it can be said that the deviation is very small while not statistically significant at the $95 \%$ confidence level. Thus, we can conclude that the model estimates can be trusted.

\section{Discussing the research model test results}

Aaker's (1991) brand equity model is the building model for products/services. According to this model, brand equity consists of four components. Factors included are brand awareness, brand association, perceived quality, and brand loyalty. Jacobsen's model (2012) is the model developed from his 2009 theoretical model. This is a model that has been developed from Keller's theory of product/service branding (2003) and built for a locality. According to this model, local brand equity consists of six elements, namely, local brand personality, local brand awareness, perceived quality, local brand impression, local brand trust, and local brand image.

The same research on brand equity, however, shows that the components that constitute brand equity in the two models above are different, which can be explained by the difference between products. Products can be both goods or services, however, in our particular case products stand for a locality. Many previous studies have shown that the same research methodology applied to different commodity products leads to very different constituents of brand equity.

The proposed here research model has been, in some sense, inherited from Jacobsen (2009). In it, there are six independent variables and one dependent variable. The EFA analysis results show that the indicators of brand personality and brand impression both lead to the independent variable. This tells us that the two-factor scale as in (Jacobsen, 2009) is not really clear. So, in the context of Vietnam (its three big cities especially), the investors' survey results show that this two-factor scale is actually measuring the same concept.

The results of testing the research model as per Jacobsen (2009) confirm that there are four local brand factors affecting the decision of domestic investors who choose investment locations. These four factors are namely brand awareness, brand image, brand personality, and brand trust. It can be seen that this model is not really suitable for Vietnamese context. 


\section{INFLUENCE OF LOCAL BRANDS ON DOMESTIC}

Furthermore, the survey subjects in our study are domestic investors, while the survey subjects in Jacobsen's study (2009) were foreign investors. Assessment of local investors' perceptions and behavior and those of the investors from another country in relation to a local brand would obviously have certain differences.

(1) The impact of local brand personality on the domestic investor's choice of investment locations

The research hypothesis $\mathrm{H} 1$ is accepted at the significance level of 95\%: The local brand personality and investor's decision to choose investment locations are positively related. This means that, when a locality is suitable, attractive and is really good for business, the investor's decision to choose this very investment location will be high. This result is consistent with the research results of (Jacobsen, 2009).

According to the results of qualitative and quantitative research, the positive correlation of local brand personality and domestic investor's decision to choose investment locations is explained by the views of investors. Local brand personality is measured by the relevance, attractiveness for business activities of enterprises, really good geographical location and availability of useful natural resources. In particular, geographical location and natural resources have been found in many previous studies to have a relationship with attraction of investments to a locality.

Today, in the race to attract investment capital, every locality improves its investment environment, promotes investment process as such and has preferential policies for investors. According to investors themselves, the above factors of localities can be created and perfected over time, however, geographical location and natural resources are natural conditions that are there by default, they cannot be created by localities. In addition, there are localities with high quality infrastructure, various local preferential policies, but still they are not necessarily suitable for investors. The suitability here can be considered to be consistent with the investment objectives, investment sectors, target markets, resources and various other factors. Therefore, investors will carefully consider all of the above while making their decision.

(2) The impact of local brand awareness on domestic investor choice of investment locations

The research hypothesis $\mathrm{H} 2$ has been rejected, as there is no basis to confirm that local brand awareness affects domestic investors' choice of investment locations. This research result is consistent with the research results of (Jacobsen, 2009). This result can be explained as follows:

Vietnam is a country with a long-standing agricultural culture of thousands of years. One of the key cultural characteristics of the Vietnamese people is avoidance of change and/or the fear of risks. People in Vietnamese society feel intimidated by ambiguous situations and try to avoid such situations by finding a stable job, establishing strong rules, researching and analyzing the information carefully, avoiding non-standard ideas and behaviors. At the same time, Vietnamese people also have the mentality of using brand names as the latter make them feel more familiar with the situation. The familiarity level is directly proportional to the level of awareness. The process of making a customer/investor decision is sometimes based only on such feelings of familiarity. And this feeling of familiarity comes from brand awareness.

In the field of investment, many researchers have shown that risk attitudes affect individual investors' decisions on the stock market where individual investors are often 
unreasonable, they are averse to risk, at the same time, in some cases, they prefer risk. Investors at the B2B market usually tend to be more cautious while making investment decisions, the risk-aversion characteristic is more evident in them, as they usually make their decisions stemming from sufficient information and assurance of some guarantees, that is, having more certainty. This is especially applicable to the investors that are making a choice of investment location: they need to be well aware of a particular locality and they need to see that the likelihood of success in that locality is high enough. Therefore, awareness of local brands has a great influence on domestic investors' decisions concerning investment locations.

(3) The impact of perceived quality on domestic investors' decision to choose investment locations

The research hypothesis $\mathrm{H} 3$ confirms that the quality of domestic investors' perception and decisions on investment locations have a positive relationship. Our research results show that sig $<0.05$. Thus, there is no basis to confirm hypothesis H3. This result is consistent with the research results of (Jacobsen, 2009). Foreign investors' behavior differs from that of domestic ones, especially in terms of the formalization of the selection process and the means of project mobilization. In the process of choosing investment locations, foreign investors are often influenced by the so-called national effect, that is, they often prioritize the selection of localities that already have other international companies present and comply with the requirements of the investment site selection process. At the same time, the importance of the factors influencing foreign investors' decisions regarding investment locations is also different from those applicable to domestic investors.

According to investors themselves, perceived quality reflects the investor's assessment of public administrative services and working methods of local authorities. These factors are considered by investors as an obvious condition when investing in local businesses. At the same time, this also reflects that, over some time, the locality has gradually perfected its administration and has met the requirements in part of public administrative services and professional working methods. Without this key attribute, investors may not choose the locality where they invest or do their business.

(4) The impact of local brand trust on domestic investors' choice of investment locations

The research hypothesis $\mathrm{H} 4$ is accepted at the significance level of 95\%: local brand confidence and domestic investors' choice of an investment location have a positive relationship. This research result is consistent with the results of a theoretical overview of local brand equity. Brand personality creates confidence in local brands. According to the research results, local brand personality has a positive relationship with the investor's choice of an investment location. This means that brand personality affects domestic investors' decisions, thereby forming confidence in local brands.

Trust is a kind of social capital which can contribute as much as financial capital, human capital, or infrastructure capital do. When people have faith in something, they will act accordingly. Investors are usually very careful when searching and selecting certain investment locations. When investors have confidence in the local government, they will choose that locality as a location for business investment. Our research results on hypothesis $\mathrm{H} 4$ are consistent with the results concerning hypotheses $\mathrm{H} 2$ and $\mathrm{H} 3$. At the investment market, the customer is the investor, while the supplier is often the local government. Thus, at this market, trust and confidence are important factors that are of special interest for 


\section{INFLUENCE OF LOCAL BRANDS ON DOMESTIC}

domestic investors. Other factors such as infrastructure, natural resources, public administrative services, the working methods of the local government can be improved gradually over time, they are also basic conditions imperative for localities.

Many countries in the world have been operating according to the model of the socalled "state enterprise": the state is considered to be an enterprise providing various public services to society. This, inter alia, means that the state is the seller of public services while the investor is the customer buying these public services. In this type of relationship, the state must optimize utilities for customers, providing the highest quality of services at the lowest possible cost, thereby building confidence for investors, so that they believe all services will be delivered at the right time and at the right price, with a dedicated attitude and commitment. When investor confidence is spread within the locality, it also gradually spreads beyond the administrative boundaries of that locality.

When there is a belief in a friendly and transparent environment, investors will be willing to invest in production and business in all the local areas of opportunity, then the government plays the role of constructively shaping the local environment. In particular, when confidence in production and business activities is verified, investors and other members of the local business community will become powerful investment campaigners, sometimes even more meaningful and successful than the public policies calling for investment promotion. Thus, local brand trust has a positive influence on domestic investors' choice of investment locations. When there is confidence in a locality, investors will be ready to make a decision and choose that locality as a place for future investment. On the contrary, if there is no confidence in a locality, investors will not choose that locality as their investment destination.

(5) The impact of local brand image on domestic investors' decisions

The study accepts the hypothesis H5 with the confidence level of 95\%: Local brand image and domestic investors' decisions have a positive relationship. This result is consistent with the research results of (Jacobsen, 2009) and also those of (Metaxas, 2010). At the same time, in accordance with the local marketing point of view, a locality with a positive image will bring a stronger competitive advantage, for investors especially.

Considering the Vietnamese context, this result is completely consistent. Building local brands in some localities around Vietnam has clearly demonstrated the influence of the image of local brands on the choice of investment locations made by domestic investors through the use of local brand image in attracting investment capital and creating grounds for further local economic development.

In the case of Danang city specifically, to build a local brand and attract investment, Da Nang has used the key local images such as infrastructure, being a coastal city, and people to create awareness among domestic and foreign target customers. The city has been using the image of central capital, a friendly and livable locality, the city of marine tourism, the destination for tourism, thus, both commercial and real estate investors became interested.

Another example is Quang Ninh province. It also succeeds in using two pillars of local brand image to influence the decisions concerning investment location selection. This city uses its image of the transit center within the northern region and the world's natural heritage of Ha Long. 
Dong Thap province has the image of "pink lotus land". Its friendly local government stems from the three key economic pillars: high-tech agriculture, ecotourism, and labor export.

Finally, Ho Chi Minh City operates the image of the Pearl of the Far East with its wellknown slogan "A civilized city, modern, meaningful".

At the market of investment locations, investors often do not have enough information. Due to the complexity and strategic nature of the investment site selection process, companies looking for these sites need to gather large amounts of information to be able to make well-informed and grounded decisions. Therefore, investors often spend a lot of time and money to get the information necessary for their decision-making process. Local information and local brand image become an important reference channel for investors. Thanks to this channel, investors have direct access to detailed information on investment locations, under reduced cost of information collection at the same time. Such information will motivate investors to make wise decisions while choosing the locality as their investment destination.

(6) The impact of local brand impression on domestic investors' decision

The study's hypothesis H6 is accepted with the confidence level of 95\%: local brand impression and domestic investors' choice of investment locations have a positive relationship. This result is consistent with the research results of (Jacobsen, 2009) and also results of (Metaxas, 2010). At the same time, in accordance with the local marketing point of view, a locality that makes a strong positive impression will have a strong competitive advantage to demonstrate to investors.

Impression is an intangible brand asset. The goal of brand impression is to evoke positive emotions on the side of customers. A local brand impression refers to a local appearance that evokes positive emotions. Therefore, local brand impressions include macrofactors such as urban aesthetics (Anholt, 2005) and also the factors that are purely local and microgeographic (Kubacki \& Skinner, 2006), and then also physical factors (Kavaratzis, 2007) as well as local natural resources (Jacobsen, 2009).

Macrofactors also include the degree of urbanization as well as the state of the urban environment, while microfactors include transport infrastructure (Fombrun and van Riel, 1997), commerce and cultural infrastructure (Anholt, 2005; Winfield-Pfefferkorn, 2005) and also architecture (Dinnie, 2008).

Our research has confirmed that local brand awareness has a positive impact on domestic investors' choice of investment locations. Local brand impression is an important stage in the shopping process and also an important criterion for measuring brand strength. The more impressive a brand is, the more popular it is and the more chances it has to be chosen by customers. The perception level can be divided into three different levels here: (i) The top level is the first recognizability of brand; (ii) The next level is not to remind but to be remembered; (iii) The lowest level is represented by reminders that serve to remember. Combining these three levels of brand impression will lead to the total number of brand associations.

In local marketing, the customer's buying process is very similar to the investor's decision-making process concerning the choice for an investment location. The investment site selection process consists of several successive phases which can be combined into three main phases: (i) First, there is listing of all possible sites involved; (ii) Next is to consider various locations according to the preset criteria that investors are interested in; (iii) 


\section{INFLUENCE OF LOCAL BRANDS ON DOMESTIC}

Ultimately, it is making the actual choice. In this decision-making process, brand awareness impacts all three stages. At the first stage, when all potential and relevant locations are grouped into a listing, the locality that first comes to mind will usually have the highest chance of being selected. At the second stage investors consider and evaluate different investment locations according to the standards they are interested in. At this, each locality produces a certain amount of brand associations which will help investors to make their investment decision more easily. At the third stage, investors will, most probably, choose the locality with the highest rating, which is a locality in which they perceive the most positive difference over other localities, and which, at the same time, has a great potential for production and business activities of investors and always shows concern about investors' interests.

Therefore, in order for the increase in brand impression to be highly effective at a reasonable cost, a province needs to determine the level of brand impression as applied to different types of investors and thus have specific solutions for each object aiming to create an association, or improve its association level, or maintain the current level in the long term. A local brand with a high degree of brand associations will truly be different and thus would be able to drive investors to choose the locality as their investment location.

\section{Conclusion and directions for future research}

The research results show that the attitudes and behavior of investment firms and also of the standalone investors towards local brands depend on the decision concerning an investment location and how well the latter can create a truly working environment. From the investor's standpoint, this would depend not only on what that the investor themselves brings to this locality. In addition, investor's perception of the correlation between the needs of enterprises investing in their work with the satisfaction of investment needs from the incentive mechanism and the local working environment as one factor is very important.

Investors also develop an awareness of their contribution to the locality, and this awareness usually correlates with the local legal and regulatory services provided by various public departments and the local administration overall. Provision of such services, to some extent, provides a comparison between investors' needs and local responses to these needs Therefore, the incentive policies and other factors of the local working environment should be based on the contribution of investors to the locality as well as on the implementation of internal communication within the locality. Thus, investors would have a reasonable awareness of the reasonable adequacy between investors' needs and local responses to these needs.

This study was carried out in three major cities in Vietnam considering only the influence of certain selected factors of the local brands on the choice of a locality as an investment destination. Thus, measuring the impact of these factors within only a limited segment of Vietnam's investment will obviously produce rather limited results. Future research in the same direction will provide more necessary information on the investment industry factors and the related incentive mechanisms in Vietnamese context. 


\section{References:}

Aaker, D.A. (1991). Managing Brand Equity. The Free Press, New York.

Anholt, S. (2005). Some important distinctions in place branding. Place Branding, 1 (2), 116-121.

Chi, H. K., Huang, K. C., \& Nguyen, H. M. (2019). Elements of destination brand equity and destination familiarity regarding travel intention. Journal of Retailing and Consumer Services, 52 .

Cleave, E., Arku, G, Sadler R., \& Gilliland, J. (2016). The role of place branding in local and regional economic development: bridging the gap between policy and practicality. Regional Studies, Regional Science, 3 (1), 207-228.

Dao Trung Kien, Tran Manh Toan, Bui Quang Tuyen, Nguyen Van Duy, \& Nguyen Thi Lien (2014). The impact of local brand attributes on investment enterprise satisfaction: Evidence from Hai Duong. Journal of Economics and Development, 210 (1), 43-52.

Davis, S., \& Douglass, D. (1995). Holistic approach to brand equity management, Marketing News, $29(2), 4-5$.

Dinnie, K.J. (2008). Nation Branding: Concepts, Issues, Practise. Butterworth-Heinemann, Oxford.

Hankinson, G. (2001). Location branding: a study of twelve English cities. Journal of Brand Management, 9 (2), 127-142.

Jacobsen, B.P. (2009). Investor-based place brand equity: a theoretical framework. Journal of Place Management and Development, 2 (1), 70-84.

Kavaratzis, M. (2005). Place branding: a review of trends and conceptual models, The Marketing Review, 5 (4), 329-42.

Keller, K.L. (2003). Strategic Brand Management: Building, Measuring and Managing Brand Equity. Pearson, Upper Saddle River, Prentice Hall.

Kubacki, K., \& Skinner, H. (2006). Poland: exploring the relationship between national brand and national culture, Journal of Brand management, 13 (4/5), 284-299.

Metaxas (2010). Corporate social responsibility in Europe: Denmark, Hungary and Greece. Place Branding and Public Diplomacy, 6 (3), 228-243.

Meffert, H. (2000). Marketing: Grundlagen Marktorientierter Unternehmens. Gabler Verlag, Wiesbaden.

Mmieh, F. \& Owusu-Frimpong, N. (2004). State policies and the challenges in attracting foreign direct investment: a review of the Ghana experience. Thunderbird International Business Review, 46 (5), 575-599.

Nguyen, V. B., Le Quoc, N. \& Le Cat, V. (2016). Factors affecting the attraction of foreign direct investment in industrial zones in Dong Nai province. Journal of Scientific Development , 5(29).

Nguyen, \& Haughton J. (2002). Trade Liberalization and Foreign Direct Investment in VietNam. Asean Economic Bulletin, 19 (3), pp. 302-318.

Rainisto, S. (2003). Success factors of place marketing: A study of place marketing practices in Northern Europe and the United States. Doctoral dissertation. Helsinki University of Technology, Helsinki. 


\section{INFLUENCE OF LOCAL BRANDS ON DOMESTIC}

Ramkissoon, H., Uysal, M., \& Brown, K. (2011). Relationship between destination image and behavioural intentions of tourists to consume cultural attractions. Journal of Hospitality Marketing and Management, 20 (5), 575-595.

Sirgy (1982). Self-Image/Product-Image Congruity and Advertising Strategy. Developments in Marketing Science, 5, 129-133.

Wang C.Y., \& Hsu, M.K. (2010). The relationships of destination image, satisfaction, and behavioral intentions: An integrated model. Journal of Tourism \& Travel Marketing, 27(8).

Winfield-Pfefferkorn, J. (2005). The branding of city - exploring city branding and the importance of brand image. Unpublished master's dissertation. Syracuse University, New York.

Zenker, S., \& Braun, E. (2010). The place brand centre - A conceptual approach for the brand management of places. $39^{\text {th }}$ European Marketing Academy Conference, Copenhagen, Denmark, 1-8.

Paper submitted

Paper accepted for publishing

Paper published online
26 February 2021

17 March 2021

31 May 2021 